\title{
Implications of the hydrotropic function of intralenticular ATP in cataractogenesis and presbyopiogenesis
}

\author{
Jack V Greiner $^{1 *}$ and Thomas Glonek ${ }^{2}$ \\ ${ }^{1}$ Schepens Eye Research Institute of Massachusetts Eye \& Ear, Department of Ophthalmology, Harvard Medical School, Boston, MA, USA \\ ${ }^{2}$ MR Laboratory, Midwestern University, Downers Grove, IL, USA
}

Adenosine triphosphate (ATP) prevents protein aggregation. The crystalline lens, although a metabolically quiescent organ, synthesizes a large amount of ATP, ca. $3 \mathrm{mM}$ [1], that exceeds by an order-of-magnitude the concentration required for all the known intracellular functions of ATP, combined. This high intralenticular ATP concentration is shared by many species including humans $[2,3]$. The production of such an excessive amount of ATP is inconsistent with the usual conservative production of ATP assumed to be operant in nature, which brings into question why such a high concentration of ATP exists in the lens.

The first measurement of the concentration of ATP in a structurally intact living tissue was made using phosphorus-31 magnetic resonance spectroscopy ( ${ }^{31} \mathrm{P}$ MRS) in striated muscle [4], and a concentration of ca. $5 \mathrm{mM}$ in muscle was corroborated [5,6]. This ATP concentration at the time was not recognized as being excessive, since muscle tissue was expected to have a high metabolic activity due to the nature of the tissues' function. Unlike the lens with a relative paucity of mitochondria, the high concentration of ATP in the striated muscle tissue is characterized by high numbers of large mitochondria where most of the ATP is manufactured. Although the $5 \mathrm{mM}$ ATP concentration in muscle may have been accepted as consistent with the high metabolic activity of a muscle, the $3 \mathrm{mM}$ concentration of ATP in the metabolically quiescent lens tissue was puzzlingly inconsistent. This unexpected and disturbing observation of high intralenticular ATP remained unexplained for nearly four decades.

This observation remained an enigma until the recent studies by Patel et al. [7], coupled with our observations on the interaction of the ATP phosphate groups with intralenticular water [8]. Patel et al. found high concentrations of ATP in cell and tissue homogenates of normal and pathological preparations and postulated that the ATP was functioning to prevent protein aggregation and could even function in reversing protein aggregation. Moreover, Patel et al. demonstrated that a large concentration of ATP $(5-10 \mathrm{mM})$ was required for such functions. This finding in cells and tissue homogenates, though not in intact functioning tissue, such as muscle, or in an intact functioning organ, such as the lens, nevertheless offered a clue as to why such excessively high concentrations of ATP existed in the intact tissue.

Further support for ATP's function as a hydrotrope is corroborated by our report of a relationship of intralenticular ATP and perturbations in ex vivo ${ }^{31} \mathrm{P}$ MRS signals of ATP's phosphate groups when the lens is incubated in deuterium oxide $\left(\mathrm{D}_{2} \mathrm{O}\right)$. Changes in the signal-narrowing of the terminal gamma-phosphate group relative to the alphaphosphate group in the lens tissue incubated in $\mathrm{D}_{2} \mathrm{O}$ are indicative of a hydrotropic function. This observation, coupled with the observations of high concentrations of ATP functioning as a hydrotrope, led to not only an explanation for the millimolar concentrations of ATP reported in the lens but allowed for a concept of a novel hypothesis [9] for how the ATP hydrotropic function could explain prevention of cataract [9] and even presbyopia [10], two of the most common of eye diseases. The etiopathology of both of these diseases is known to be protein aggregation that occurs with aging and can manifest in clinically observable biomicroscopic signs (cataract) and symptoms (presbyopia) past midlife. This hypothesis has particular significance, considering the lens has the greatest concentration of proteins in the body and a unique structural arrangement of proteins that further support such a hypothesis. This hypothesis recognizes the rheologically dynamic interface of ATP with intracellular water that mitigates protein aggregation which results in both opacification (cataract) and less flexibility or stiffening (presbyopia) of the lens organ.

The hypothesis was developed by considering ATP as an amphiphilic molecule present in the intralenticular milieu with its adenine moiety bound in a nonpolar interaction to hydrophobic regions on lens fiber cell protein molecules. Such bonding can convert the naturally hydrophobic regions on a lens protein molecule to being recognized as hydrophilic by intralenticular water. With the joining of the adenine moiety of the ATP molecule to hydrophobic protein regions, the triphosphate portion of the ATP molecule becomes oriented with its charged phosphate groups extending into the intralenticular water between proteins (Figure 1). Support for such orientation is established using ${ }^{31} \mathrm{P}$ MRS experiments [8].

Incubating ex vivo lenses in $\mathrm{D}_{2} \mathrm{O}$ provided evidence for the interaction of the ATP phosphate side-chain groups with the water surrounding the proteins, such that the gamma-phosphate group was the most mobile, indicating its extension into the interstitial mobile water phase (Figure 1) [9]. The prevention of - and the potential for reversal of-protein aggregation in cells is important for multiple reasons, the most important of which is the maintenance of protein function. Aggregation blocks function, leading to loss of cellular functional capacity. The lens, being essentially a bag of highly organized proteins, is an extreme example of proteins crowded into a congested space, but the principles discussed here apply to all living cells in those regions within cells where functional proteins are concentrated. In

${ }^{\star}$ Correspondence to: Dr. Greiner, Schepens Eye Research Institute of Massachusetts Eye \& Ear, W239, 20 Staniford St, Boston, MA 02114, E-mail: Jack_Greiner@meei.harvard.edu

Received: May 23, 2020; Accepted: July 06, 2020; Published: July 13, 2020 


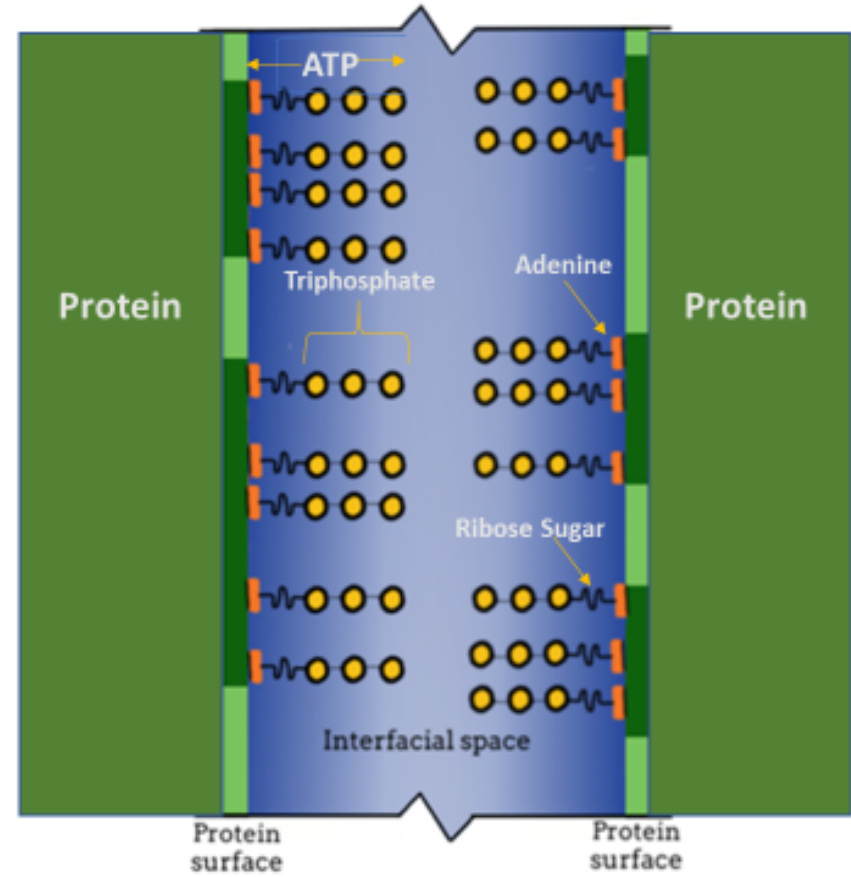

Figure 1. Schematic representation depicting the relationship between adjacent protein molecules, hydrotropic ATP molecules, and the interfacial space between the protein surfaces. This space is filled with interstitial water (blue), bounded by two adjacent proteins (vertical green lines, dark green portions represent hydrophobic regions), with the ATP [adenine (orange), ribose sugar (short wavy line)] triphosphate side-chains (yellow) projecting into the interstitial water

the lens, protein aggregation and loss of function results in decreased transparency (cataract) and visual accommodation (presbyopia). In the brain, aggregation is a hallmark of Alzheimer's disease, and in muscle it is a consequence of Duchenne's dystrophy and other muscle wasting diseases. Because, at least in the laboratory, ATP can reverse protein aggregation, it is conceivable that by controlling the concentration of tissue ATP, protein aggregation could be prevented or in early disease states reversed and some measure of cellular function restored for the benefit of an afflicted patient.

\section{Acknowledgement}

Supported in part by the Valerie and Walter Winchester Grant, Schepens Eye Research Institute of Massachusetts Eye \& Ear, Harvard Medical School, Boston, MA.

\section{References}

1. Greiner JV, Kopp SJ, Sanders DR, Glonek T (1981) Organophosphates of the crystalline lens: A nuclear magnetic resonance spectroscopic study. Invest Ophthalmol Vis Sci 21: 700-713. [Crossref]

2. Kopp SJ, Glonek T, Greiner JV (1982) Interspecies variations in mammalian lens metabolites as detected by phosphorus-31 nuclear magnetic resonance. Science 215 : 1622-1625. [Crossref]

3. Glonek T, Kopp SJ. Ex vivo P-31 NMR of lens, cornea, heart, and brain. Mag Reson Imag 3: 359-376. [Crossref]

4. Glonek T (1974) Personal communication.

5. Hoult DI, Busby SJW, Gadian DG, Radda G, Richards RE, et al. (1974) Observation of tissue metabolites as detected by ${ }^{31} \mathrm{P}$ nuclear magnetic resonance. Nature 252: 285287. [Crossref]

6. Bárány M, Bárány K, Burt CT, Glonek T, Myers TC. Structural changes in myosin during contraction and the state of ATP in the intact frog muscle. J Supramol Struct 3: 125-140. [Crossref]

7. Patel A, Malinovskaya L, Saha S, Wang J, Alberti S, et al. (2017) ATP as a biological hydrotrope. Science 356: 753-756. [Crossref]

8. Glonek T, Greiner JV (1990) Intralenticular water interactions with phosphates in the intact crystalline lens. Ophthalmic Res 22: 302-309. [Crossref]

9. Greiner JV, Glonek T (2020) Hydrotropic function of ATP in the crystalline lens. Exp Eye Res 190: 1-8.

10. Heys K, Friedrich MG, Truscott RJ (2007) Presbyopia and heat: changes associated with aging of the human lens suggest a functional role for the small heat shock protein alpha-crystalline in maintaining lens flexibility. Aging Cell 6: 807-815. [Crossref]

Copyright: $\odot 2020$ Greiner JV. This is an open-access article distributed under the terms of the Creative Commons Attribution License, which permits unrestricted use, distribution, and reproduction in any medium, provided the original author and source are credited. 